\title{
L.A.S. Johnson - a botanical career
}

\author{
Barbara G. Briggs
}

\begin{abstract}
Briggs, Barbara G. (National Herbarium of New South Wales, Royal Botanic Gardens, Sydney, 2000, Australia) 1996. L.A.S. Johnson - a botanical career. Telopea 6(4): 511-520. A summary is given of the career of Lawrence (Lawrie) Johnson, who is celebrated in this special issue of Telopea. As botanist (1948-1972) and Director (1972-1985) at the Royal Botanic Gardens Sydney he has contributed to plant systematics, especially in the Casuarinaceae, Zamiaceae, Oleaceae, Juncaceae, Myrtaceae (most notably in Eucalyptus and Corymbia), Proteaceae and Restionaceae. He has been responsible for major improvement of the botanical curation of the National Herbarium of New South Wales and, as Director, the construction of the Robert Brown Building (which houses the Herbarium and Scientific Division), early stages in the development of the important satellite gardens at Mount Tomah and Mount Annan, and planning of the Tropical Centre glasshouses and of the Flora of New South Wales. In his seventy-first year he continues in research, is enthused by the new phylogenetic insights arising from DNA research, and continues to maintain high scientific standards and contribute to knowledge of plants and their evolution.
\end{abstract}

\section{Introduction}

Lawrence (Lawrie) Johnson, botanist (1948-72) and Director (1972-85) at the Royal Botanic Gardens Sydney, has contributed to botanical systematics and to knowledge of Australian plant groups for more than four decades. This issue of Telopea honours him in his seventy-first year.

Many awards over the years have recognised Johnson's achievements, especially his award as a Member of the Order of Australia (AM) for services to botanical science. He has received the Clarke Medal of the Royal Society of New South Wales, the Mueller Medal of the Australian and New Zealand Association for the Advancement of Science (ANZAAS), a D.Sc. from the University of Sydney and election as a Fellow of the Australian Academy of Science and of the Linnean Society of London (honoris causa), as well as corresponding memberships of the Botanical Society of America and the American Society of Plant Taxonomists. He also received a special informal New Year's 'honour' in 1984 from prominent Sydney journalist Leo Schofield; for improving the city of Sydney by making the Royal Botanic Gardens 'even more beautiful ... and a dynamic centre for all things horticultural'.

These are remarkable achievements for a scientist in the relatively low-profile field of systematic botany, and one who stayed in one institution for the whole of his professional career.

\section{Lawrie Johnson, botanist}

Lawrence Alexander Sidney Johnson graduated in science with first class honours from the University of Sydney in 1948. His intention since early teenage to study science went along with a generally rationalist approach to life and an interest in understanding and classifying features of the world around him. Encouragement by good science teachers at Parramatta High School was influential, rather than a particular love of plants. Indeed, he had initially intended to major in chemistry but turned his interests 
to botany after meeting the lively minds of the Botany Department at that time: Professor Eric Ashby (later Lord Ashby), physiologist Bob (later Sir Rutherford) Robertson, ecologist Noel Beadle and geneticist Newton Barber. Early in his career he also developed close contacts at the Museum of Applied Arts and Sciences in Sydney with botanists Spencer Smith-White (later of the University of Sydney) and J.L. (Jack) Willis, as well as phytochemist Howard McKern. This was a time of wide-ranging, indeed re-awakening, interest in Australia's flora and vegetation, and all these botanists were searching for understanding of processes of evolution and variation, seen in terms of ecology and physiology. In his final research year as an undergraduate some of his work was at the National Herbarium of New South Wales, the scientific arm of Sydney's Royal Botanic Gardens, where his main contacts were Anderson and Vickery.

Lawrie Johnson (LJ) joined the staff of the Herbarium in 1948. The team there in those years was growing although still small, with the Director and Chief Botanist Robert (Bob) Anderson and botanists Knowles Mair, Joyce Vickery, Mary Tindale, Alma Lee (née Melvaine), Joy Garden (later Joy Thompson), Neridah Ford, George Chippendale and Valerie Jones (née May). Herbarium Assistants and Technical Officers were unknown in the Herbarium until well into the 1960s and all curation of the collections rested with the botanists.

Another person relevant to LJ's work was Ernest (Ernie) Constable, the Botanical Collector. They made many fieldtrips together, in Ernie's old-style vans, which were scarcely adequate for the often poor roads. LJ particularly remembers Ernie's intrepid bush skills and ability to find his way, as well as how Ernie would reduce costs by seeking overnight accommodation for himself and Lawrie from his many friends in the Baptist Church or his ex-army mates. On other occasions, when camping in the bush, Ernie would cheerily wake his companions too early (in their view) with a cup of tea and an excessively hearty 'Rise and shine!'.

In the Herbarium LJ and his colleagues had inherited a rich collection which had received inadequate curation in the decades since the retirement in 1924 of that outstanding early Director, Joseph Henry Maiden. In seeking to improve the situation, emphasis was not so much on the physical curation as on improving the botanical order and information content. The specimens remained unmounted in their folders, but both Australian and non-Australian groups were now being critically assessed and arranged according to the best available revisions. The Flora of New South Wales, issued as a supplementary series to the Contributions of the New South Wales National Herbarium, was commenced. Despite the enthusiasm of the botanists, it proceeded far too slowly, and was later replaced by a Flora project along very different lines (Harden 1990-3). Johnson's treatment of the cycads was among the first and most thorough issues of this series, and an associated revision (Johnson 1959) assessed the distinctions between major cycad groups and established the families Zamiaceae and Stangeriaceae. Oleaceae followed soon after, again with major elucidation of relationships.

The final year of LJ's university studies had been spent in research on the Casuarinaceae, a group in which he has continued research intermittently for decades, jointly in recent times with Karen Wilson. He speaks of how he irritated the Western Australian Government Botanist, Charles Gardner, by indicating his own intention to assess various Casuarina (subsequently Allocasuarina) species then recently described by Gardner. Now LJ has long recognised why his early comments were seen as brash by that very senior botanist. Over the years Johnson's expression of his views has changed from the brashness of youth, but has not been muted. He has sometimes been seen as unduly vehement, particularly by those whom he considered did not live up to his expectations of logical thought, clear expression or wide knowledge. He has always held opinions strongly, and strongly criticised those who disagreed, while being prepared to change his opinions 
if presented with a convincing array of evidence. Some scientists have found LJ to be a stern critic but others have found him a supporter. He has especially supported several botanists whose views were being rejected primarily for their unorthodoxy, rather than being rejected on evidence. In such cases LJ would call for a reconsideration of the facts.

Shortly after Johnson's appointment at the Herbarium, Anderson was revising his book Trees of New South Wales. LJ did much of this work, over a range of tree genera, (but with Mary Tindale responsible for Acacia). By that time Lawrie was married and his wife Merle typed large sections of the revised book, for which both of them received only limited acknowledgment. He did, however, receive from Anderson much encouragement, friendship and some insight into administration, though management was very different then from today's excess of managerial requirements that affect organisations worldwide.

LJ soon took on the role of providing botanical expertise for the principal Australian tree group, the eucalypts, and this has continued to dominate much of LJ's subsequent research over more than four decades. With more than 800 species now recognised, the eucalypts are a vast assemblage, dominating most of Australia's vegetation except in the arid inland. Their study is made complex by the subtle features by which species differ, the extent of hybridism, and the diverse patterns of wide-ranging and narrowly endemic or disjunct distributions. In this work LJ found compatible scientific approaches in Lindsay Pryor (Director of Parks and Gardens in Canberra and later Professor of Botany at the Australian National University) and colleagues Don Blaxell (later Assistant Director, Living Collections at the Royal Botanic Gardens, Sydney) and Ken Hill (now Senior Botanist). Ian Brooker (now of Australian National Herbarium, CSIRO) has been another important contact in eucalypt studies.

All these collaborators shared LJ's strong belief in the value of field studies and travelled extensively. With Pryor, and his colleague Dugald Paton, this sometimes involved extensive light aircraft trips. Decades later, when beset by back and neck problems (the latter from a whiplash injury while travelling from a scientific conference), LJ still considered it worthwhile to see species in the field. 'Just give me time to straighten up' would be his comment as he stiffly got out of the four-wheel drive vehicle on fieldwork in remote regions.

It has been in expressing the complexities of the eucalypts that LJ has most clearly shown his determination that logic should override conservative conventions. Most eucalypt specialists have seen the value of (and used) the 'extracodical' subgenera and series of Pryor \& Johnson (1971 and subsequent papers), although there has been less use than he hoped of the codes of up to six letters to summarise the classification of each taxon at all levels of the hierarchy. These efficient means of expressing groupings were largely devised by LJ, although published jointly.

LJ has shown himself precise and particular in nomenclature, orthography and typification at the predominant levels of family, genus and species, and he has served in these areas on committees of the International Association for Plant Taxonomy. But he soon came to regard rigid application of the rule of priority as an irrelevant timewaster for taxa at intermediate levels which derive their significance only from their circumscription (content) in a particular classification. As he emphasises, his usages that do not follow the International Code of Botanical Nomenclature are extracodical rather than informal, they are part of a formal and precisely defined logical system. In the same spirit in which he determined on these usages, he welcomes many of the measures now being proposed by Werner Greuter, John McNeill and David Hawkesworth (e.g. Hawkesworth et al. 1994) to remove unnecessary instability in biological nomenclature - this 'senior citizen' of botany has in no way become a conservative. 
At times LJ has received unwarranted criticism as 'the person intent on splitting up Eucalyptus and changing all their names'. He greatly regretted that irrelevant arguments were brought to bear on a matter that should be settled by experts considering evidence and logic, not by numbers of voices. In the event, ideas that Eucalyptus should be divided into about 12 genera have not been implemented; he and colleagues have considered it necessary at this stage to make only the most essential change - removal of a group of 113 species to form Corymbia (Hill \& Johnson 1995) - reserving judgement on possible further change.

A notable change of scene came with his appointment in 1962 for 15 months as Australian Botanical Liaison Officer at the Royal Botanic Gardens, Kew. This experience was botanically rewarding but was marred by the miserly policy of the State Government towards its employees at that time. In the event, despite Anderson's efforts and although such appointments were then normally for two-year periods, support for his travel did not extend to his family. The New South Wales Public Service Board even suggested that another botanist with no dependants be chosen, rather than a man with a wife and four (soon to be five) children. Always strongly supportive of Lawrie's career, Merle stoically insisted that he should take up the opportunity for valuable overseas experience while the family remained in Sydney. At the time of this, his first overseas travel and visits to Europe and North America, they did not know that Merle would later work for an airline administration, earning opportunities for much overseas travel for all the family.

Over the decades systematics had not stood still. By the 1950s chromosomal studies had come forward as the latest of a series of new technical developments. Both Joyce Vickery and Lawrie Johnson encouraged the introduction of these approaches into the Herbarium. With the 1960s came the numerical taxonomists, pheneticists with their statistical procedures, which Johnson rejected.

Around this time LJ had taken up mathematics as a serious interest, aided by evening courses in modern mathematical concepts, filling a gap in his scientific education. (These courses overlapped others in the Russian language, as part of his continuing interest in languages worldwide.) The logical processes of mathematics stimulated his close analysis of the theoretical basis of the pheneticists' arguments. He expressed his reasons for rejecting their approaches in 'Rainbow's End' in 1968, his main publication on theoretical systematics, which was widely acknowledged and reprinted in the journal Systematic Zoology in 1970.

Considerations of evolutionary relationships and classification in the prominent southern hemisphere families Proteaceae, Myrtaceae and Restionaceae have been major areas of research, and I was fortunate to collaborate with him on each of these. Our first joint work of this type was an uneven partnership; as stated in Johnson \& Briggs (1963), I provided chromosome counts on Proteaceae while the greater part of the morphological data and interpretation was by LJ. Our later collaborative work was more evenly divided, but his incisive mind always focused quickly on the critical issues to be resolved. He was appreciative of the work of colleagues, but was active in studying specimens or anatomical or other preparations to assure himself of the substance of the findings and interpretations. When discussing the work he would often sum up the data or conclusions in words that needed little modification before incorporation into manuscripts. Proteaceae and Myrtaceae were each the subject of two major papers and work in both families is now being taken further, by colleagues Peter Weston and Peter G. Wilson respectively.

Typifying LJ's approach, the studies became extremely broad-ranging, extending into considering each family in relation to the whole of the flowering plants, to past tectonic movements and environments, as well as to pollinators and seed dispersal. 
Plate tectonics, still doubted by some outspoken geologists when Johnson \& Briggs (1963) was completed, had become the accepted wisdom by 1975 , giving new significance to the interpretation of southern hemisphere distributions. Hypotheses were developed of the past history of the Proteaceae, in relation to the land-masses on which they occur (Johnson \& Briggs 1975), and have served as a basis for many subsequent discussions of that family and of data from a range of disciplines. Consideration of inflorescence structures in Myrtaceae (Briggs \& Johnson 1979) led to an assessment, revision and summary of the subfamily, tribal and generic classification of this large family, and also to a substantial review of the terms and concepts used in analysing and comparing inflorescences generally.

Typically also, as in much of Johnson's work, these papers are concise summaries of a great deal of information that was not presented in detail but that was rigorously compiled and critically assessed. Some of the conclusions, and the evidence on which they were based, have subsequently been overlooked at times because they have appeared only in this condensed style. For example, to illustrate and describe in detail all the pericarps of fruits of Proteaceae that were sectioned could have been useful, but it would have vastly increased the work. This was not feasible while meeting deadlines, with little technical assistance, and especially since most research was done after $6 \mathrm{pm}$ when administrative matters could be set aside by both those involved. The forbearance of Merle Johnson with these long hours must be applauded.

Work on Restionaceae, the third of these 'old southern families' (Johnson \& Briggs 1981), arose out of earlier work for the Flora of New South Wales in the 1960s that showed that the generic classification was highly unsatisfactory. Other priorities slowed the study of this family and it remains in the 1990s an active interest, and was greatly aided by the technical help of Carolyn Porter and DNA sequencing by Simon Gilmore.

The second of the Proteaceae papers (Johnson \& Briggs 1975) also outlined a phylogenetic approach to classification and to determining evolutionary relationships. This was independent of Hennigian cladistics but based on somewhat similar thinking, linking groups only on apomorphies. Around this time, with the assistance of his oldest son, Christopher, this procedure was expressed in their computer program CLAX. This was based on an algorithm mirroring the procedures of a taxonomist by grouping together those taxa (OTU's) with most synapomorphies in common and then continuing, in a top-down procedure, to the less closely associated taxa with fewer apomorphies. Before the procedure was computerised LJ and I generated trees, especially in Myrtales, through manual calculation according to this algorithm, considering near-minimal groupings as well as minimals at all stages in tree-generation. The speed and ease of computerised programs now available contrasts with the long days and evenings of manual computation. Because of other competing priorities, Chris and LJ did not succeed in fully de-bugging the computer version of CLAX, and now that PAUP with its many options (Swofford 1990) is conveniently available LJ has no intention of proceeding further with CLAX. While using cladistic procedures he stresses the need to consider carefully the biological implications of character changes and believes that parsimony should not over-rule such considerations.

A further aspect of Johnson's botanical contribution should be mentioned, his help to less experienced botanists who found him a wise advisor and friend. A very large number of publications have acknowledged his constructive comment or discussion with him. Botanists working with him gained valuable insights from his approach. Mostly this applied to younger botanists, but he guided a much older colleague when Obed Evans, formerly head of botanical technical staff at the University of Sydney, joined the Herbarium staff as a part-time botanist. Johnson and Evans worked on several monocot families including Cyperaceae, a project on which Karen Wilson 
assisted after Evans' final retirement and, with LJ's encouragement, she later took over and greatly developed. Also started with Evans was a study of Restionaceae of New South Wales, which later led to the much wider project with myself.

Through discusssion and comment LJ sought to raise the standard of Australia's systematic work, especially encouraging many others to consider their taxonomic decisions in the light of a broad spectrum of evolutionary thinking. In Sydney, by promoting an environment of lively discussion and concern for scientific standards, he helped to gather and foster a staff of active, wide-ranging systematists. He was important too in encouraging ecological colleagues and sound ecological approaches, as discussed by Benson (this issue).

From the 1950s to the early '70s when National Parks and Wildlife Service organisations were lacking or embryonic in Australia, there were only a few ecologists with broad knowledge of the flora and vegetation. Systematists had been major champions of nature conservation and served in some roles that would now mostly fall to ecologists. Joyce Vickery had set an example in this and LJ further developed this influential role, especially as an expert member of Government committees (see Benson, this issue).

LJ had been a member of the Flora of Australia Committee of ANZAAS (the Australian and New Zealand Association for the Advancement of Science) and part of a delegation in 1960 to put the case to the Prime Minister's Department seeking support for a national Flora project. He was appointed to the committee that eventually led to success in that aim, the Interim Council of the Australian Biological Resources Study. During 1973-5 that committee set guidelines, helped to make clear to the Federal Government the great need for the Flora of Australia, and visited institutions in major centres to discuss biologists' needs and to promote the new projects envisioned. The Flora program received Australian Government funding from 1979 and has been acknowledged internationally as highly effective, its success partly based on the associated grants program and the establishment of the core of editorial staff overseeing the work.

\section{Director, Royal Botanic Gardens Sydney}

LJ's period as Director, 1972-1985, proved a time of major progress and, especially while Neville Wran was Premier of New South Wales (1976-86), major projects were funded and changes implemented.

LJ had seen Directors of the Gardens submerged in administrative and horticultural detail, and it was only when he acted briefly in the position before the appointment of Dr John Beard that he realised how the Directorship could be handled differently. He saw that change was possible with a clear concept of the role of the organisation and vision for its future (Johnson 1985), even though the Royal Botanic Gardens was still a peripheral part of the New South Wales Department of Agriculture for administrative purposes.

The NSW Government, by Act of Parliament, in 1980 set up the Royal Botanic Gardens and Domain Trust. LJ had very cordial relations with, and received strong support from, the Trust and especially the Trust Chairmen of his time, Sir Alexander Beattie, Professor Michael Pitman and Mr John Ferris. Administratively the Gardens moved from the New South Wales Department of Agriculture to be associated with the Premier's Department in 1980. It found a compatible home among the cultural institutions there until, after the retirement of both Premier Neville Wran and LJ, it was moved to the Environment portfolio.

A major aim in LJ's early years as Director was to obtain funding for a new building to house the Herbarium collections and scientific programs. Trust Chairman Sir Alexander 
Beattie and LJ eventually convinced Premier Wran of the urgency of the need. When funds were obtained LJ took a substantial part in the planning process, with colleagues and excellent architects Andrew Andersons and Brian Zulaikha, and defended the project against objections at that time from the Council of the City of Sydney.

Completion of the Robert Brown Building in 1982 provided laboratories and reasonable working conditions for the first time in decades. This also paved the way for the Visitor Centre (later Gardens' Shop), the holding of exhibitions and even the formation of the Friends of the Royal Botanic Gardens. A Friends Society had been almost impossible without some meeting space - which was made available by moving the collections out of the old building. LJ and his botanical colleagues took a very active part in organising the XIII International Botanical Congress in Sydney in 1981. Many overseas visitors saw the crowded conditions soon to be vacated, since the new building was not completed for occupation until early the following year. At the opening of the building a sister-garden relationship with the Missouri Botanical Garden was announced, arranged through Dr Peter Raven, the eminent Director of that Garden.

It is interesting that, although LJ's enthusiasm was greatest for the scientific work of the organisation, and he always spoke vigorously of its scientific importance, much of the development during his Directorship was in projects of a more horticultural nature. Indeed these would, as he predicted, shift the balance of the organisation towards its living collections rather than its botanical programs. LJ always hoped that these developments would, nevertheless, contribute to community appreciation and understanding of the natural world through education and awareness programs. Education programs within the Gardens had been initiated by Director John Beard and were now expanded under LJ's direction, including visits by Education Officers to remote schools in western New South Wales, while knowledgeable volunteer guides enhanced the experience of many visitors to the Gardens. Social change was also by now in evidence with women joining the horticultural staff.

The Mount Tomah Botanic Garden was developed on land that had been offered to the Royal Botanic Gardens in the 1960s. Work and planning proceeded slowly until the Gardens were successful in obtaining development funds from the Australian and New South Wales governments. A Gondwanan theme, an initiative of LJ, became a major element in the plantings.

Mount Annan Botanic Garden fulfilled an earlier hope, going back to the 1920s when Joseph Maiden sought to establish an arboretum in the south-west of Sydney, a hope that was now exceeded. With the Premier's support, at LJ's instigation, a suitable site was located and the project was planned and funded. He especially welcomed the greatly enlarged opportunity it presented to grow plants of known provenance and relevance to research, as well as to reach a wider community.

Both the Mount Tomah and Mount Annan Gardens became Bicentennial projects, commemorating the Bicentennial of European settlement on this continent. Development, under LJ's direction, was ably implemented by Don Blaxell (Assistant Director, Living Collections) with planning help from the NSW Government Architect's Branch. Both were opened to the public after LJ's retirement, under his successor Professor Carrick Chambers.

By now the journals Telopea in systematics and Cunninghamia in ecology had replaced the former Contributions from the New South Wales National Herbarium. Publication committees and refereeing systems were established and the scientific output greatly increased. LJ was less enthusiastic about the development of computerised databases, although he realised that these were now needed, and though these were initiated during his directorship, linking the organisation's living collections and herbarium. 
With LJ's encouragement the Flora of New South Wales was planned and work started in 1982, with funding and encouragement from the Trust. This four-volume work, edited and co-ordinated by Gwen Harden, was completed and published during Professor Chambers' directorship.

The Pyramid Glasshouse had been planned during the directorship of Knowles Mair but opened while LJ was Director. A further large display glasshouse in the Sydney Gardens was now also planned and a substantial private donation towards its cost obtained, but construction did not occur until after LJ had retired. It now forms the greater part of the Tropical Centre.

During this very busy time of major expansion, LJ greatly regretted that the resources of the organisation were spread so thinly that horticultural standards in the Sydney Gardens suffered. He hoped that consolidation and remedying such problems would follow the period of major expansion. Resources have continued to be limiting but new developments since his retirement have added features of quality, adding greatly to the interest of the Gardens to visitors.

An advocate for a brief after-lunch siesta, followed by work late into the evening, he managed to 'protect' a siesta time most days (helped by secretaries and colleagues) even in his very busy years as Director, a daily program he has continued to the present.

\section{In retirement}

LJ did not intend to retire in 1985 but Government policies of that time strongly favoured youth employment and he found that retirement at age 60 years (rather than the expected 65) was demanded. This was in sharp contrast to policies opposed to age-discrimination in employment implemented only a few years later. Retiring when so many developments he had started were yet to come to fruition was a bitter matter, and this coloured his view for some years.

Among the gifts from his colleagues when he retired was a large dictionary of Anglo-Saxon, a strange but appreciated gift for an Australian scientist. This reflects his intense interest in comparative languages. He delights in comparing the processes of development, modification and migration of languages with the processes of biological evolution. Respect for other languages, for him, includes correct pronunciation, and he perseveres in trying to improve his less informed colleagues' expression of foreign words, as well as of botanical names. The guide to pronunciation of botanical names, included in Hall \& Johnson (1993), took these efforts to a wider audience.

On retirement LJ was appointed by the Royal Botanic Gardens Trust as Director Emeritus and as an Honorary Research Associate. To continue effectively in research LJ required access to the collections at the National Herbarium of NSW, collections he had helped to build up. His successor as Director, Professor Carrick Chambers, actively supported LJ's continued role as a researcher here in retirement, when - somewhat later - others queried an ex-Director continuing at an institution he no longer directed. LJ's time as Director is in the past, his role as scholar and researcher continues.

Most of the groups with which he has been concerned remain as active research interests, and a major study in the eucalypts jointly with Ken Hill has been completed (Hill \& Johnson 1995). Other active projects are in Juncus and Casuarinaceae with Karen Wilson, and in Restionaceae and allied families with myself, Carolyn Porter, Simon Gilmore, Barbara Wiecek and previously Vivian Shanker, Anna-Louise Quirico and Siegfried Krauss. 
LJ has been highly supportive of the development of a DNA laboratory for molecular plant systematics at the Royal Botanic Gardens and has actively followed literature in this important field. He was enthusiastic, as I was, when Honorary Research Associate Professor John Thomson helped us, with lunchtime 'lessons', to gain better understanding of this fast-moving discipline. [Professor Thomson would not use the term 'lessons' but rather 'discussions', but they were education by an expert of those who were much in need of patient instruction.] Macromolecular systematics is, in LJ's view as well as mine, now the most important source of new phylogenetic understanding. In conjunction with critically assessed morphology and phylogenetic reasoning this has given systematics a new excitement. With the work of Peter Weston, John Thomson, Peter Wilson and Simon Gilmore, the scientific standards that LJ did much to develop have been extended into new areas.

LJ continues to serve on the Council of the Linnean Society of New South Wales, of which he has had two terms as President. He also continues to keep better informed on current scientific literature than many much younger botanists. The botanical advisory staff at the Herbarium find him to be a source of vast knowledge and helpful in sharing his ability to identify plants and impart botanical information. For his part, LJ values the day-to-day contact with younger scientists, who are concerned with accuracy, quality and promoting wider community knowledge and understanding.

Apart from botany and languages, his enthusiasms - all actively shared with Merle - have continued to be music, family (now finding time for excursions with his grandchildren), travel, railways, good food and wine, and tennis with family and younger friends.

We wish Lawrie Johnson many more healthy, satisfying and productive botanical years.

\section{Acknowledgements}

I wish to thank my colleagues for constructive comments on the manuscript.

\section{References}

Benson, D. (1996) L.A.S. Johnson: taxonomist, ecologist, conservationist ... botanist sens. lat. Telopea 6: 521-526.

Briggs, B.G., \& Johnson, L.A.S. (1979) Evolution in the Myrtaceae - evidence from inflorescence structure. Proc. Linn. Soc. New S. Wales 102: 157-256.

Hall, N. \& Johnson, L.A.S. (1993) The Names of Acacias of New South Wales with a Guide to Pronunciation of Botanical Names (Royal Botanic Gardens: Sydney).

Harden, G.J. (1990-93) Flora of New South Wales, vols 1-4 (NSW University Press: Kensington).

Hawkesworth, D.L., McNeill, J., Sneath, P.H.A., Trehane, R.P. \& Tubbs, P.K. (1994) Towards a harmonized bionomenclature for life on earth. Biology International 30.

Hill, K.D. \& Johnson, L.A.S. (1995) Systematic studies in the eucalypts. 7. A revision of the bloodwoods, genus Corymbia. Telopea 6: 185-504.

Johnson, L.A.S. (1959) The families of cycads and the Zamiaceae of Australia. Proc. Linn. Soc. New S. Wales. 84: 64-117.

Johnson, L.A.S. (1968) Rainbow's End: the quest for an optimal taxonomy. Presidential address. Proc. Linn. Soc. New S. Wales 93: 8-45.

Johnson, L.A.S. (1970) [Republication of] Rainbow's End: the quest for an optimal taxonomy (with addendum). Syst. Zool. 19: 203-239.

Johnson, L.A.S. \& Briggs, B.G. (1963) Evolution in the Proteaceae. Austral. J. Bot. 11: 21-61.

Johnson, L.A.S. (1985) Whence, where, whither? - the Royal Botanic Gardens in review. Pp. 10-13 in Annual Report 1984-1985 (Royal Botanic Gardens: Sydney). 
Johnson, L.A.S. \& Briggs, B.G. (1975) On the Proteaceae - the evolution and classification of a southern family. J. Linn. Soc. (London) Bot. 70: 83-182.

Johnson, L.A.S. \& Briggs, B.G. (1981) Three old southern families - Myrtaceae, Proteaceae and Restionaceae. Pp 427-469 in A. Keast (ed.), Ecological biogeography of Australia (W. Junk: The Hague). Pryor, L.D. \& Johnson, L.A.S. (1971) A classification of the eucalypts (Australian National University: Canberra).

Swofford, D.L. (1990) PAUP: Phylogenetic analysis using parsimony version 3.0. Illinois Natural History Survey, Champaign, Illinois.

Manuscript received 1 September 1995

Manuscript accepted 14 December 1995 